\title{
Present or Absent? About a Threatened Fern, Asplenium adulterinum Milde, in South-Eastern Carpathians (Romania)
}

\author{
Attila BARTÓK ${ }^{1}$, Irina IRIMIA ${ }^{2 *}$ \\ IActavis, 11 Ion Mihalache Blvd, 011171, Bucureștí Romania; bartok.attila@gmail.com \\ 2Alexandru Ioan Cuza University, Faculty of Biology, 20A Carol I Blvd, 700506, Iaşi, Romania; iblaj2002@yahoo.com(*corresponding author)
}

\begin{abstract}
Asplenium adulterinum Milde is one of the rarest and most threatened representatives of the Aspleniaceae family in the Carpathians. Botanical literature mentioned the ladder spleenwort in many localities in South-Eastern Carpathians in the past, but during the last decades the species has not been collected and deposited in public herbaria by any botanist. All existing herbarium material in Romanian herbaria (including $A s p l e n i u m$ trichomanes and $A$. trichomanes-ramosum) was revised and all available information from botanical literature was critically compiled in order to clarify the distribution of Asplenium adulterinum in the South-Eastern Carpathians. After almost 80 years since the first mention of the species in the Carpathians, this paper reports the recent identification of Asplenium adulterinum in three new locations in South-Eastern Carpathians (Țesna Valley, Vânturătoarea Waterfall and Şugăului Gorges).
\end{abstract}

Keywords: Aspleniaceae, chorology, endangered species, flora, Red Book, threatened species

\section{Introduction}

Asplenium L. is a relatively large genus of Aspleniaceae family with about 700 species. They are also one of the most widespread fern groups and occur in temperate and tropical regions of all continents, except Antarctica (Schneider et al., 2004). Thirtyone species of this genus are present in European flora (Crabbe $e t$ al., 1993), ten of these species occurring in Romanian flora (Asplenium scolopendrium L., A. septentrionale (L.) Hoffm., $A$. trichomanes L., A. trichomanes-ramosum L., A. adulterinum Milde, A. ruta-muraria L., A. lepidum C. Presl, A. cuneifolium Viv., A. adiantum-nigrum L., A. onopteris L.) (Sârbu et al., 2013).

Some fern species of Asplenium genus (Asplenium adulterinum, $A$. adiantum-nigrum and $A$. cuneifolium) are often called serpentine ferns, because their occurrence is almost strictly related to serpentine rocks (Hayek, 1916). Serpentinites is a rock composed of one or more serpentine group minerals. Serpentinization is a geological low-temperature metamorphic process involving heat and water, in which low-silica mafic and ultramafic rocks are oxidized and hydrolysed with water into serpentinite. Serpentinite is formed from olivine via several reactions, some of which are complementary (Sleep et al., 2004).

Serpentinites have a limited number of characteristic plants, which are confined exclusively to magnesium silicates or carbonates (serpentine, magnesite) and these species may be considered strictly serpentine species. In Europe, serpentinites occur in the Alps, Carpathians, Balkan Peninsula, Southeast Portugal and Great Britain (Roberts and Proctor, 1992). In Romania they grow in South-Eastern Carpathians (Southern Carpathians and Apuseni Mountains, less in the Eastern
Carpathians) (Corvin Papiu, 1963). Serpentine ferns are extremely rare and have been declining at an alarming rate.

The present study focuses on Asplenium adulterinum Milde, one of the rarest and most threatened plant species in the Romanian flora. Asplenium adulterinum was included in the list of species as an extension to Annex II of the Habitat Directive (Directive 92/43/EEC) so that its protection requires the designation of a Special Area of conservation. It was also listed together with Asplenium cuneifolium in Annex IV of The Convention of European Wildlife and Natural Habitats (Bern Convention) concerning plant species demanding strict protection in all European Union countries.

Asplenium adulterinum was considered to be an European endemic species (Holderegger, 1994) before it was found on Vancouver Island, Canada (Klinkenberg, 2008). Also, the species is considered a glacial relict (Holderegger, 1994). The first description of the species was made by Milde (1865). Asplenium adulterinum is considered a natural hybrid between $A$. trichomanes and A. trichomanes-ramosum (Lovis and Reichstein, 1968; Reichstein, 1984). Asplenium adulterinum is a vascular cryptogam whose roots are not proliferous. Stems are shortcreeping, mainly unbranched; scales are black or with narrow pale borders, narrowly lanceolate (with dimensions $1.5-3 \times 0.2-$ $0.4 \mathrm{~mm}$ ), with entire margins. Leaves are monomorphic. Petiole is dark reddish brown (1-4 mm). Blade is linear, 1-pinnate (2.5$14 \times 0.5-1.2 \mathrm{~cm}$ ), thick (in open habitat) to herbaceous (in shaded, moist habitat), essentially glabrous; base is somewhat tapered; apex is obtuse, not rooting. Rachis is reddish brown in proximal $1 / 2-4 / 5$ part and green in distal part, lustrous, glabrous. Pinnae are in 10-30 pairs, ovate to rhombic to ovate-oblong (with dimensions of 2.5-11 $\times 2-6 \mathrm{~mm}$ ), very short petiolated; 
300

base is truncated to shortly acute; margins are shallowly crenate (shade forms) to essentially entire (exposed forms); apex is obtuse, broadly rounded. Sori are linear with 1-3 pairs per pinna. Spores are 64 per sporangium (Wagner Jr. et al., 1993).

The species occurs on ledges and crevices of ultrabasic rocks (serpentine, magnesite) or rarely on basic rocks. Asplenium adulterinum Milde subsp. presolanense Mokry, Rasbach \& Reichst. occurs in North of Italy and South of Switzerland on limestone or mica-schist (Crabbe et al., 1993).

In the Romanian botanical literature Asplenium adulterinum is considered a rare species (Boşcaiu et al., 1994; Oltean et al., 1994; Oprea, 2005) or placed in the "Insufficiently Known" (K) sozological category (Dihoru and Dihoru, 1994). The species was included in the Red Book of Vascular Plants of Romania (Dihoru and Negrean, 2009). Inclusion in a sozological category of species in Romania was difficult, considering that the fern has not been seen by botanists in recent decades. Since 1931 no botanist has collected Asplenium adulterinum from the Romanian Carpathians and deposited in a public herbarium (in reality there is a single herbarium voucher in BUCA Herbarium (BUCA no. 004147), whereas the plant was collected by Grinţescu on 3 July 1931, near Băile Herculane, but the data have never been published.

According to the Red Book of Vascular Plants of Romania (Dihoru and Negrean, 2009) it seems that there is also a specimen deposited in the CL herbarium: "Custura Mătaniei, 12 VII 1964, N. Boşcaiu [CL]”. The authors hereby checked this information in CL herbarium (on 15 and 16 January 2015) and did not find any specimens of Asplenium adulterinum.

\section{Materials and Methods}

The investigations were based on recent field studies and analysis of herbarium material stored at CL, BUCA, BUCF, BVS, SIB, I, IAGB, IASI, B, W, WU, P, CRAI (acronyms according to Thiers, 2015), as well as literature data. All existing herbarium material (including Asplenium trichomanes and $A$. trichomanes-ramosum) was revised and all available information from botanical literature was critically compiled in order to clarify the distribution of Asplenium adulterinum in the SouthEastern Carpathians.

Several field surveys were made between 2004 and 2014 in Almăjului Mts., Aninei Mts., Mehedinți Mts., Țarcu Mts., Ceahlău Mts., Hăşmaş Mts., Călimani Mts., Rarău Mts. (SouthEastern Carpathians) where the species was reported.

Phytosociological characteristics of possible sites with Asplenium adulterinum were studied according to the BraunBlanquet approach (Braun-Blanquet, 1932).

The collected material has been lodged in the personal herbarium of A. Bartók.

\section{Results and Discussion}

Distribution of Asplenium adulterinum Milde in SouthEastern Carpathians

\section{Rarău Mountains, Eastern Carpathians}

Pietrele Doamnei (Lady's Stones) and their surroundings represent maybe the most intensively investigated region by the botanists, considering the whole range of Rarău Mountains.

In this mountain range the presence of Asplenium adulterinum was reported by some authors (Mititelu et al., 1989;
Oprea and Sârbu, 2012, 2013; Bădăău, 2013), but without exact localisation and never confirmed by herbarium material. The main botanists (Morariu, 1965; Raclaru, 1973, 1976) who investigated in detail the mountain and subalpine flora of Rarău Mountains did not mention Asplenium adulterinum; they both refer only to Asplenium trichomanes-ramosum and Asplenium trichomanes.

During the current research surveys, the species was not found near Pietrele Doamnei or in other parts of this mountain group (Bartók A, pers. obs. 2007, 2010, 2011, 2014). It can be said that certainly it was confused here with Asplenium trichomanes-ramosum or Asplenium trichomanes, since these two species are frequently encountered in the region.

\section{Călimani Mountains, Eastern Carpathians}

Neither Csürös (1951) nor Höhn (1998a) mentioned Asplenium adulterinum in the area of Călimani Mountains. However, Mititelu et al. (1986) and Chifu et al. (2008) reported ladder spleenwort in the flora of this mountain range, but without exact localisation or citation. Although Höhn (1998a) did not mention Asplenium adulterinum in the flora of Călimani Mountains, the same author highlights in another publication (Höhn, 1998b) (according to personal observations) that species with affinity for basic soils (e.g. Asplenium adulterinum Milde, Carex sempervirens L., Phyteuma orbiculare L., Saxifraga adscendens L.) do not occur on the south part of Călimani Mountains, but on the north face.

Yet, the most recent checklist of Călimani National Park (ICB Iaşi, 1994) does not mention Asplenium adulterinum in Călimani Mountains. Since it is known that the list of Mititelu $e t$ al. (1986) is partly based on older literature without citations, Asplenium adulterinum could not be observed in the field (Bartók A, pers. obs. 2007, 2010, 2011) and therefore it can be concluded that is was confused with Asplenium trichomanesramosum or Asplenium trichomanes, since these two species are frequently encountered in this region. There are no herbarium specimens of Asplenium adulterinum from the floristically well explored Călimani Mountains, in all herbaria checked.

\section{Bistriței Mountains, Eastern Carpathians}

Asoltani (2007) listed Asplenium adulterinum in this mountain range from Şaru Bucovinei and Şeştină, but it was not confirmed by herbarium voucher. Seghedin in his thesis and in floristically synthesis of Suceava County (Seghedin, 1985, 1987) did not mention Asplenium adulterinum, but Asplenium trichomanes-ramosum and Asplenium trichomanes instead, in this mountain group. Also Mardari (2008) in a floristical synthesis of Bistriței Mountains flora could not confirm the presence of ladder spleenwort in this area.

The flora of this mountain range is not well studied, and the presence of Asplenium adulterinum remains doubtful (there was no herbarium voucher in all checked herbaria).

\section{Hăşmaş Mountains, Eastern Carpathians}

Asplenium adulterinum was first listed in this mountain group by Nechita and Mititelu (1996) and Nechita (2000) in two separate phytosociological papers, in composition of two plant associations: Asplenietum trichomano-rutae murariae Kuhn 1937, Tx. 1937 (in Bicăjel Gorges and Piatra Singuratică Mts., Hăşmaş Mountains, Eastern Carpathians) and Asplenio- 

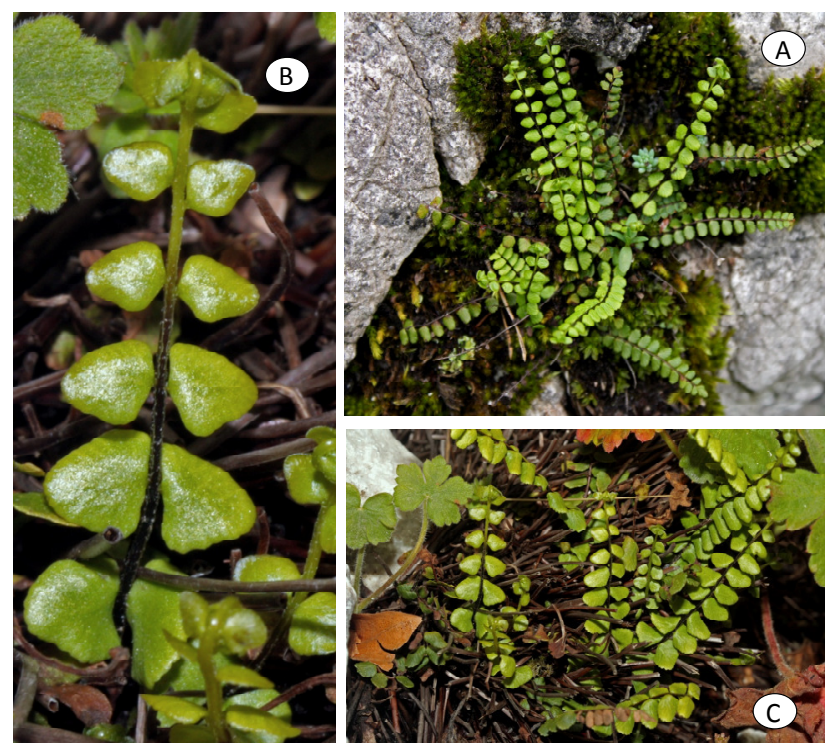

Fig. 1. A: Habitus of Asplenium adulterinum, growing on limestone rocks, near Şugăului Gorges (original photo by Ioana Popescu); B, C: Habitus of Asplenium adulterinum, growing on limestone rocks, in Țesna Valley (original photo by Adrian Schlesinger)

Cystopteridetum fragilis Oberd. (1936) 1949 (in Hăşmaşul Mare, Hăşmaşul Negru and Hăşmaşul Mic Mts., Hăşmaş Mountains, Eastern Carpathians). Interestingly, the same author in a floristical and phytosociological monograph of Hăşmaş Mountains (Nechita, 2003) did not include the relevés where Asplenium adulterinum was present.

Asplenium adulterinum was listed by Nechita (2003) in Suhardul Mic Mountains, but unfortunately the citation was erroneously based on Soó publication (Soó, 1940); the cited paper was probably confused with another one (Nagy, 1942) in which Asplenium $\times$ breynii Retz. (Asplenium trichomanes $\times$ Asplenium septentrionale) was mentioned, not Asplenium adulterinum.

The flora of Hăşmaş Mountains and Bicazului Gorges was well explored and other floristical or phytosociological publications (Guşuleac, 1932; Nyárády, 1937; Soó, 1940, 1943; Ştefan et al., 2007) did not mention the occurrence of Asplenium adulterinum in this mountain range. Horeanu (1979) did not mention Asplenium adulterinum in the floristical paper regarding flora of Munticelu-Cheile Şugăului Nature Reserve, but Asplenium trichomanes-ramosum or Asplenium trichomanes instead.

However, Nechita and Bliderişanu (2006) listed ladder spleenwort in Bicazului Mts. but without exact locality or citation. The species was reticently mentioned to appear in Stânişoarei Mountains (Oprea and Sârbu, 2008, 2009). It might be supposed that the mentioned coronim (Bicazului Mts.) refers to the Northeastern part of Hăşmas Mountains, which is situated near Stânişoarei Mountains. Bădărău (2013) mentioned Asplenium adulterinum in "Cheile BicazuluiHăşmaş” (ROSCI 0027) Natura 2000 network, but without exact locality or citation. Also, ladder spleenwort is listed in the Management Plan of Cheile Bicazului-Hăşmaş National Park, but without exact locations or citation. There are no herbarium vouchers of Asplenium adulterinum in all checked herbaria.
Moreover, ladder spleenwort was recently reported on Munticelu-Cheile Şugăului Nature Reserve near Şugăului Gorges by Associate Professor Dr. Ioana Popescu (Fig. 1, photo A). Herbarium material was not collected, but in the pictures taken it is clear that the colour of rachis is green in distal part. Asplenium adulterinum is growing here in a non-typical habitat on limestone rocks (the studied area does not include serpentine rocks) (Corvin Papiu, 1963).

\section{Ceabläu Mountains, Eastern Carpathians}

Grecescu in his floristical monograph (Grecescu, 1906) did not mention Asplenium adulterinum in Ceahlău Mountains, but Asplenium trichomanes-ramosum or Asplenium trichomanes instead. Neither later studies in this mountain range (Panţu, 1911; Grințescu, 1923; Nyárády, 1924; Papp, 1931; Borhidi, 1958; Burduja, 1962; Horeanu and Borcea, 1982) did not mention ladder spleenwort from the floristically well explored Ceahlău Mountains. In more recent publications (Chifu et al., 1987; Manoliu et al., 2002), the authors mentioned Asplenium adulterinum in Neamt, County (Ceahlău Mountains), but without exact locality or citation. Also Bădărău (2013) mentioned Asplenium adulterinum in "Ceahlău" (ROSCI 0024) Natura 2000 network, but without exact data or citation.

Ladder spleenwort is listed in the Management Plan of Ceahlău National Park, but without exact data. There are no herbarium specimens of Asplenium adulterinum from the floristically well explored Ceahlău Mountains in all checked herbaria.

Evenmore, Asplenium adulterinum could not be found in this mountain group (Bartók A, pers. obs. 2004, 2005, 2006, 2007,2009 , 2011). Similar as in other mountain range in the Eastern Carpathians, Asplenium adulterinum was probably confused with the omnipresent Asplenium trichomanesramosum or Asplenium trichomanes, which are well documented (Grecescu, 1906; Papp, 1931; Manoliu et al., 2002) as proved by numerous vouchers in I, IAGB or IASI.

\section{Mebedinți Mountains, Southern Carpathians}

This mountain range was not well explored floristically; only Domogled Peak with its surroundings and T,esna Valley were studied more rigorously from the botanical point of view. Borbás (1874) and Simkovics (1878) followed by Degen (1901) studied the flora of Domogled Massif, without any report about the occurrence of Asplenium adulterinum in this mountain group, but Asplenium trichomanes-ramosum and Asplenium trichomanes instead. Nor the more recent research of Resmeriță (1970, 1971, 1972) did not demonstrate the occurrence of ladder spleenwort in the floristically explored Tesna Valley. Neither Georgescu (1934) nor Buia (1959) or Bujorean and Popescu (1966) mentioned Asplenium adulterinum for the Mehedinți Mountains.

In the document compiled by Faculty of Biology and Geography - Babeş-Bolyai University Cluj-Napoca - "Research about flora and vegetation of the parcels with Banat black pine from the Domogled-Valea Cernei National Park" (2006) the occurrence of Asplenium adulterinum was mentioned in this mountain range, but without any specific locality or citation. Moreover, the authors of this publication recognized the absence of the species on field. Bădărău (2013) mentioned Asplenium adulterinum in "Domogled-Valea Cernei" (ROSCI 0069) Natura 2000 network, but without exact locality or citation. 
302

A previously unknown citation about a population of Asplenium adulterinum was noted in Mehedinți Mountains (Southern Carpathians) on 1 June 2013, reffering to the middle part of the TesnaValley, in semi shady rocky place, exposed to the north, at approximately $600 \mathrm{~m}$ a.s.l. Asplenium adulterinum was growing there in a non-typical habitat: on limestone rocks, in crevices of rocks, not far from the tourist path. Although the authors of the current study researched in detail a great part of the area, a single individual was found. Accordingly, it may be supposed there was a very small population in that place. Because a single specimen was found, herbarium material was not collected. This discovery was documented by photos (Fig. 1. B, C).

Additionally, it is worth mentioning that only one voucher specimen of Asplenium adulterinum from Romanian Carpathians was found in all herbaria consulted (BUCA no. 004147). The plant was collected by Grințescu on 3 July 1931 near Băile Herculane (in humid rock crevices), the only specimen previously known from the Romanian Carpathian, but the data have never been published.

Mehedinți Mountains are one of the few mountains in Romanian Carpathians wherein the presence of this rare fern was confirmed.

\section{Cernei Mountains, Southern Carpathians}

The area of Arjana Peak and Vânturătoarea Waterfall from Cernei Mountains, shelter a very interesting flora, with rare species e.g. Minuartia graminifolia (Ard.) Jáv. subsp. hungarica Jáv., considered endemic for Southern Carpathians (Conti, 2003). There are no previous collected herbarium specimens of Asplenium adulterinum or floristic data about this species in the Cernei Mountains.

During the current study field research, a population of Asplenium adulterinum was identified on 27 April 2014, near Vânturătoarea Waterfall, in adumbral rocky place, exposed to the north, at $550 \mathrm{~m}$ a.s.l. Asplenium adulterinum was growing there in a non-typical habitat: on limestone rocks, in crevices of rocks. The area is protected; it is included in Domogled-Valea Cernei National Park. The population was poor, counting only three specimens of plants. The population was probably more numerous, but it was not possible to examine the whole area in detail. The collected material waslodged in the personal herbarium of A. Bartók.

\section{Tarcu Mountains, Southern Carpathians}

This area was studied by Borbás (1874) and Simkovics (1878) who did not report the occurrence of the fern. The first mention of the presence of Asplenium adulterinum in Tarcu Mountains was signalled by Boşcaiu (1971) who investigated the flora and vegetation of this mountain range. Boşcaiu (1971) reported Asplenium adulterinum population in T,arcu Mountains, near Custura Mătaniei at an altitude of 1,750 m a.s.l., slope $80^{\circ}$, on a surface of $9 \mathrm{~m}^{2}$, in a single phytosociological relevé (Asplenietum trichomano-rutae murariae Kuhn 1937, Tx. 1937). Bădărău (2013) mentioned Asplenium adulterinum in "Munții T,arcu” (ROSCI 0126) Natura 2000 network, but without exact locality or citation. Based on this publication, Asplenium adulterinum was included in Management Plan of "Munții Țarcu” (ROSCI 0126) Natura 2000 protected area.

There are no herbarium specimens from the Tarcu Mountains in all checked herbaria. Moreover, the authors could not find Asplenium adulterinum in the area of Custura Mătaniei nor in other parts of this mountain range (Bartók A, pers. obs.
2013, 2014), but Asplenium trichomanes-ramosum instead.

Unfortunately, the occurrence of Asplenium adulterinum in T,arcu Mountains remains doubtful.

\section{Almäjului Mountains, Western Romanian Carpathians, Banat} Mountains

The flora of Almăjului Mountains was relatively well studied, but the presence of Asplenium adulterinum was not yet demonstrated by herbarium material.

Volume I of Romanian flora (Grintescu, 1952) mentioned the occurrence of ladder spleenwort in Danube Gorges on the serpentine massif between Poiana Mraconia and Baia Nouă, but without any specific location or citation. It is curious that Grințescu did not specify Cernei-valley coronim in Flora of Romania, although he collected herbarium material in 1931. There is no publication (before 1952) which listed the presence of this rare fern in that mountain range.

Matacă (2005) mentioned the occurrence of Asplenium adulterinum in Portile de Fier Nature Park, but she only cites the Romanian flora (Grințescu, 1952). Other publications (Borbás, 1874; Simkovics, 1878; Hayek, 1916; Borza, 1931; Resmeriță et al., 1968; Csürös et al., 1968; Pop et al., 1969; Dihoru et al., 1972) did not list the presence of ladder spleenwort in this mountain group. Bădărău (2013) mentioned Asplenium adulterinum in "Porțile de Fier" (ROSCI 0206) Natura 2000 network, but without exact locality or citation.

The area of "Cazanele Mari" is dominated by serpentine rocks (the ideal substrate for Asplenium adulterinum) and in the authors' opinion this is the explanation for undocumented citation of this rare fern in the mountain group.

Asplenium adulterinum could not be found near Cazanele Mari nor in other parts of this mountain range (Bartók A, pers. obs. 2009, 2010, 2011, 2012, 2013, 2014), but Asplenium trichomanes instead.

Aninei Mountains, Western Romanian Carpathians, Banat Mountains

In this mountain range, the presence of Asplenium adulterinum was reported once (Peia, 1982) in a short floristical paper; the author only listed a few species and specified their locations (e.g. Asplenium adulterinum on rocks in Rudăriei Gorges). New floristical and phytocenological papers (Grigoriu et al., 2005; Imbrea et al., 2014) highlighted that ladder spleenwort was listed in older literature (Peia, 1982), but it was not recently identified in the field. Bădărău (2013) mentioned Asplenium adulterinum in "Cheile Rudăriei" (ROSCI 0032) Natura 2000 network, but without exact locality or citation. Floristical and phytocenological research in Nerei Gorges (Anina Mountains) (Schrött, 1968, 1969, 1972, 1996) did not demonstrate the occurrence of Asplenium adulterinum in this mountain group. Peia (1978) did not mention ladder spleenwort in other floristically interesting area of Aninei Mountains, Minişului Gorges. Also Nicolin, in her publications regarding Minişului Gorges and Izvorul Bigăr protected area (Nicolin and Imbrea 2007, 2009) did not mention the occurrence of Asplenium adulterinum in those areas.

Ladder spleenwort could not be found in Aninei Mountains (Bartók A, pers. obs. 2011, 2013). There are no herbarium specimens of Asplenium adulterinum from that mountain range in all checked herbaria. 


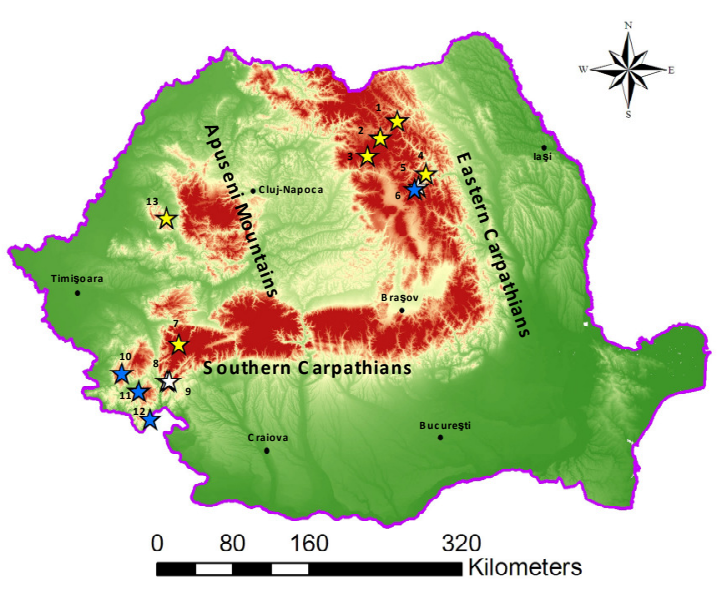

Fig. 2. Chorological map of Asplenium adulterinum distribution in South-Eastern Carpathians; the white star represents certain location, the blue star represents possible locations, the yellow star represents uncertain locations of $A$. adulterinum in the Romanian Carpathians

Legend: 1-Rarău Mountains; 2-Bistriței Mountains; 3-Călimani Mountains; 4-Ceahlău Mountains; 5,6-Hăşmaş Mountains; 7-Țarcu Mountains; 8-Cernei Mountains; 9-Mehedinți Mountains; 10,11Aninei Mountains; 12-Almăjului Mountains; 13-Codru-Moma Mountains.

\section{Codru-Moma Mountains, Western Romanian Carpathians,} Apuseni Mountains

In the area of Codru-Moma Mountains, Asplenium adulterinum was mentioned in Izbuc Brook (Briheni village) by Burescu and Păşcuţ (2010) in a phytosociological paper. The authors only mentioned the presence of ladder spleenwort within Asplenium trichomano-rutae murariae Kuhn 1937 association, but without other comments of this important biogeographical and floristical finding. In this plant association, the ladder spleenwort would be present together with Poa nemoralis L. and Doronicum columnae Ten.

The flora of this mountain group was studied by Paucă (1936, 1941a, 1941b), but the occurrence of this rare fern was not mentioned. There are no herbarium specimens of Asplenium adulterinum from that mountain group in all checked herbaria.

In contrast, Asplenium trichomanes coming from this mountain range was well documented in the Romanian botanical literature.

Habitat description of Asplenium adulterinum Milde in Romanian Carpathians

According to the Romanian phytosociological literature, Asplenium adulterinum is a species that grows on rocks (Chifu, 2014), characteristic for TortuloCymbalarietalia and Asplenietalia septentrionalis orders.

Boşcaiu (1971) comprises Asplenium adulterinum in Asplenietum rutae-murariae plant association which occurs in alpine part of Țarcu Mountains (e.g. gabbroic breccia from Custura Mătaniei) together with: Asplenium trichomanes-ramosum L., Cystopteris fragilis
Table 1. Associations of Asplenio-Silenetum petraeae Boşcaiu 1971

\begin{tabular}{|c|c|c|}
\hline Exposition & North & North \\
\hline Slope (degrees) & $80^{\circ}$ & $85^{\circ}$ \\
\hline Altitude (m, a.s.l.) & 600 & 550 \\
\hline Surface $\left(\mathrm{m}^{2}\right)$ & 1 & 2 \\
\hline Relevé no. & 1 & 2 \\
\hline \multicolumn{3}{|l|}{ Char. ass. } \\
\hline Asplenium ruta-muraria & 1 & 1 \\
\hline Asplenium trichomanes & 3 & 2 \\
\hline Silene saxifraga subsp.petraea & 2 & 2 \\
\hline \multicolumn{3}{|l|}{ Micromerion pulegii } \\
\hline Athamanta turbith subsp. hungarica & - & + \\
\hline Ceterach officinarum & 1 & + \\
\hline Dianthuspetraeus & + & - \\
\hline Edraianthus graminifolius & + & - \\
\hline Micromeria pulegium & + & + \\
\hline \multicolumn{3}{|l|}{ Cystopteridion } \\
\hline Poa nemoralis & + & + \\
\hline \multicolumn{3}{|l|}{ Tortulo-Cymbalarietalia } \\
\hline Asplenium adulterinum & + & + \\
\hline \multicolumn{3}{|l|}{ Asplenietea trichomanis } \\
\hline Saxifraga paniculata & 1 & - \\
\hline Sedum telephium subsp. maximum & घ & + \\
\hline \multicolumn{3}{|c|}{ Stipo pulcherrimae-Festucetalia pallentis s.l. } \\
\hline Alyssoides utriculata & - & + \\
\hline Draba lasiocarpa & + & - \\
\hline Silene flavescens & - & + \\
\hline Veronica crassifolia & + & - \\
\hline \multicolumn{3}{|l|}{ Variae syntaxa } \\
\hline Geranium rotundifolium & 1 & - \\
\hline Arabis collina & + & घ \\
\hline
\end{tabular}

Place and date of relevés: 1. Mehedinţi Mts., middlepart of Ţesna valley, limestone rocks and screes (1.VI.2013); 2. Cernei Mts., near Vânturătoarea Waterfall, limestone rocks and screes (27.IV.2014)

(L.) Bernh., Asplenium ruta-muraria L., Asplenium trichomanes L., Silene pusilla Waldst. \& Kit.

It was mentioned in "Vegetated siliceous inland cliffs" (Corine 62.2) or "Acid siliceous inland cliffs" (EUNIS H 3.1) (Doniță et al.,2005).

Based on the current study field research, analysis of stored herbarium material and literature data, it was developed the chorological map of distribution of Asplenium adulterinum in Romanian Carpathians (Fig. 2).

\section{Field observations}

During the botanical trips in the Mehedinți and Cernei Mountains (2013 and 2014, respectively) very rare and endangered species in Romanian flora were recorded on limestone rocks and screes, in two small phytocoenoses $\left(1-2 \mathrm{~m}^{2}\right)$ of the association Asplenio-Silenetum petraeae Boşcaiu 1971 (Table 1). The location of the two populations of Asplenium adulterinum identified in these mountains and their phytosociological context are as follows:

1) Romania, Southern Carpathians, Mehedinți Mountais, T, esna valley, alt. $600 \mathrm{~m}$ a.s.l, on limestone rocks and screes, in ass. Asplenio-Silenetum petraeae Boşcaiu 1971, total area approximately $1 \mathrm{~m}^{2}$. In this phytocenosis (Table 1 , relevé 1) Asplenium trichomanes L., Asplenium ruta-muraria L., Silene saxifraga L. subsp. petraea (Waldst. \& Kit.) Guşul. were dominant, seconded by Geranium rotundifolium L., Saxifraga paniculata L., Dianthus petraeus Waldst. \& Kit., Micromeria pulegium (Rochel) Benth., Arabis collina Ten. etc. 
304

2) Romania, Southern Carpathians, Cernei Mountais, Vânturătoarea Waterfall, alt. $550 \mathrm{~m}$ a.s.l., on limestone rocks and screes, in ass. Asplenio-Silenetum petraeae Boşcaiu 1971, total area approximately $2 \mathrm{~m}^{2}$ (leg. A. Bartók and S. I. Bartók, personal herbarium A. Bartók). In this phytocenosis (Table 1, relevé 2) Asplenium trichomanes L. and Silene saxifraga L. subsp. petraea (Waldst. \& Kit.) Guşul. were dominant, seconded by Athamanta turbith (L.) Brot. subsp. hungarica (Borbás) Tutin, Alyssoides utriculata (L.) Medik., Sedum telephium L. subsp. maximum (L.) Krock. etc.

During other botanical trip in Cernei Mountains, Southern Carpathians on 27 April 2014 Asplenium adulterinum was identified in the same phytocenosis.

In the Munticelu-Cheile Şugăului Natural Reserve (Hăşmaş Mountais, Eastern Carpathians), near Şugăului Gorges, Asplenium adulterinum was found on jurrasic limestones, together with Asplenium trichomanes, Asplenium ruta-muraria, Campanula carpatica, Aurinia saxatilis, Saxifraga paniculata, Polypodium vulgare, Thymus comosus etc. (Associate Professor Dr. Ioana Popescu, 24 May 2008).

\section{Recommended IUCN threat category}

Only three population of Asplenium adulterinum are certainly known in the Romanian Carpathians, in restricted area of Hăşmaş, in Mehedinţi and Cernei Mountains. The places where the species occurs are apparently protected (DomogledValea Cernei and Cheile Bicazului- Hăşmaş National Park), but in reality the area is exposed to human activities (e.g. tourism, grazing).

On the basis of new chorological data and estimation of the number of individuals and population condition, Asplenium adulterinum can be define as IUCN CR C2a(i) (IUCN, 2012) in Romania.

\section{Conclusions}

All available information from Romanian botanical literature was critically compiled in order to clarify the distribution of Asplenium adulterinum in the South-Eastern Carpathians.

Based on field studies, three new localities of Asplenium adulterinum (one important threatened species in Europe) were discovered. The occurrence of Asplenium adulterinum in Romanian Carpathians was recorded and the threatened status according to criteria and categories of IUCN was determined.

\section{Acknowledgements}

The auhots wish to thank the curators of CL (Dr. Mihai Puşcaş), BUCA (Dr. Sorin Ştefănuț), SIB (Dr. Ghizela Vonica), BVS (Dr. Adrian Indreica), IAGB (Dr. Adrian Oprea), CRAI (Dr. Daniel Răduțoiu) for information and photos about herbarium specimens.

\section{References}

Asoltani L (2007). Contributions to the study of the vascular flora from the Neagra Şarului River's area. Buletinul Grădinii Botanice Iaşi 14:93-98.

Bartók A, pers. obs. 2004, 2005, 2006, 2007, 2009, 2010, 2011, 2012, 2013,2014.
Bădărău AS (2013). Habitate, Plante, [Habitats, Plants]. In: Mănoiu T, Brânzan T (Eds), Catalogul habitatelor, speciilor şi siturilor Natura 2000 în România, [The catalogue of habitats, species and Natura 2000 sites in Romania]. Fundația Centrul Naţional pentru Dezvoltare Durabilă. SC Exclus Prod SRL \& RA Monitorul Oficial, Bucureşti.

Borbás V (1874). Jelentés az 1873. évben Bánság területén tett növénytani kutatásokról, [Report about botanical research in the Banat in 1873]. Mathematikai és Természettudományi Közlemémyek 7:213-291.

Borhidi A (1958). Gypsophilion petraeae foed. nova et contributions à la végétation du Mont Ceahlău (Carpathes Orientales), [Gypsopbilion petraeae foed. nova and contributions to the vegetation in the Ceahlău Mountains (Eastern Carpathians)]. Acta Botanica Academiae Scientiarum Hungaricae 4(3-4):211-231.

Borza A (1931). Botanischer fuihrer durch die umgebung von Băile Herculane (Herkulesbad) bis an die Donau, [Botanical guide about surroundings of Băile Herculane area to the Danube]. In: Borza A (Ed), Guide de la sixième excursion phytogéographique internationale, Roumanie, [Guide of the Sixth International Phytogeographic Excursion, Romania]. Le jardin botanique de L'Université de Cluj, Cluj pp 55-63.

Boşcaiu N (1971). Flora şi vegetaţia Munților Ţarcu, Godeanu şi Cernei, [The flora and vegetation of Țarcu, Godeanu and Cernei Mountains]. Editura Academiei Republicii Socialiste România, Bucureşti.

Boşcaiu N, Coldea G, Horeanu C (1994). Lista Roşie a plantelor vasculare dispărute, periclitate, vulnerabile şi rare din flora României, [Red List of extinct, endangered, vulnerable and rare vascular plants in Romania’s flora]. Ocrotirea Naturii şi a Mediului Înconjurător 38(1):45-56.

Braun-Blanquet J (1932). Plant Sociology. The Study of Plant Communities, Fifth Impression (1sted).

Buia A (1959). Plante rare pentru flora R.P.R, existente în Oltenia, [Rare plants for the flora of R.P.R, present in Oltenia]. Ocrotirea Naturii 4:13-42.

Bujorean G, Popescu PC (1966). Rezervația Naturală Domogled (Băile Herculane), [Domogled (Băile Herculane) Natural Reserve]. Ocrotirea Naturii 10:5-29.

Burduja C (1962). Muntele Ceahlău - Flora şi vegetația, [The Ceahlău Mountain - Flora and Vegetation]. Ocrotirea Naturii 6:63-92.

Burescu P, Păşcuț CG (2010). Inputs to knowledge of rocks vegetation within Codru-Moma Mountains (NW Romania). Analele Universității din Oradea, Fascicula Biologie 17:62-69.

Chifu T, Mititelu D, Dăscălescu D (1987). Flora şi vegetația județului Neamt, [Flora and Vegetation of the Neamț County]. Memoriile Secțiilor Ştiințifice ale Academiei Române 10(1):281-302.

Chifu T, Ştefan N, Asoltani L (2008). Flora şi vegetația, [Flora and Vegetation]. In: Chifu T, Manoliu A, Toma C (Eds). Parcul Naţional Călimani - Studii ecologice şi de biodiversitate, [The Călimani Natural Park - Ecological and biodiversity research], Editura Alma Mater, Cluj-Napoca pp 15-87.

Chifu T (2014). Cl. Asplenietea trichomanis. In: Chifu T (Ed). Diversitatea fitosociologică a vegetației României, Vol I. Vegetația erbacee naturală, [Phytosociological diversity of Romania. Vol I. 
Natural herbaceous vegetation], Editura Institutul European, Iaşi pp 307-364.

Conti F (2003). Minuartia graminifolia (Caryophyllaceae), a south-east European species. Botanical Journal of the Linnean Society 143(4):419-432.

Corvin Papiu V (1963). Geologie şi drumeție - Trasee în Carpații Româneşti, [Geology and excursions - Hiking in Romanian Carpathians]. Editura Ştiințifică, Bucureşti.

Crabbe JA, Jermy AC, Lovis JD, Viane R (1993). Asplenium L. In: Tutin TG, Burges NA, Chater AO, Edmonson JR, Heywood VH, Moore DM, ... Webb DA (Eds), Flora Europaea, Vol 1, Cambridge University Press (2nd ed) pp 18-23.

Csűrös Ş (1951). Cercetări floristice şi de vegetaţie în Munţii Călimani, [Floristic and Vegetation researches in Călimani Mountains]. Studii şi Cercetări Ştiințifice. Academia Republicii Populare Române Filiala Cluj 2(1-2):127-143.

Csűrös Ş, Pop I, Hodişan I, Csűrös-Káptalan M (1968). Cercetări floristice şi de vegetaţie între Orşova şi Eşelnița, [Floristic and Vegetation researches between Orșova and Eșelnița]. Contribuții Botanice:277-312.

Degen A (1901). Die Flora von Herculesbad (Eine VegetationsSkizze), [Flora of Băile Herculane (A vegetation map)]. Budapest, Buchdruckerei-Actiengesellschaft Pallas.

Dihoru G, Andrei M, Cristurean I (1972). Flora teritoriului dintre Valea Mraconiei şi depresiunea Dubova (Defileul Dunării), [Flora of the territory between the Mraconiei Valley and Dubova Depression (The Danube's Gorges)]. Acta Horti Botanici Bucurestiensis 1970-1971:479-514.

Dihoru G, Dihoru A (1994). Plante rare, periclitate şi endemice în Flora României - Lista roşie, [Rare, endangered and endemic plants of Romania's Flora - The Red List]. Acta Horti Botanici Bucurestiensis 1993-1994:173-197.

Dihoru G, Negrean G (2009). Cartea roşie a plantelor vasculare din România, [Romanian Red Book of Vascular Plants]. Editura Academiei Române, Bucureşti.

Doniță N, Popescu A, Paucă-Comănescu M, Mihăilescu S, Biriş A (2005). Habitatele din România, [Habitats from Romania]. Editura Tehnică Silvică, Bucureşti.

Georgescu CC (1934). Studii phyto-geografice în bazinul inferior al Văiei Cernei (Băile Herculane), [Phyto-geographical studies in lower basin of Cerna Valley (Băile Herculane)]. Analele ICAS 1(1):71-133.

Grecescu D (1906). Plantele vasculare ale Ceahlăului până acum cunoscute expuse subt raportul geografico-botanic şi sistematic, [The vascular plants of Ceahlău]. Analele Academiei Române, Memoriile Secțiunii Ştiințifice 28(19051906):405-489.

Grigoriu AL, Imbrea IM, Alda NR (2005). Vegetation of Cheile Rudăriei (Rudăriei Gorge), south-west of Romania, Scientific Conference State-of-the-Art and Problems of Agricultural Science Education, Agricultural Univ Plovdiv, Scientific Works, Vol L(book 6):345-350.

Grinţescu GP (1923). O escursie botanică pe Muntele Ceahlău (Carpaţii Moldovei), [A botanical trip in the Ceahlău Mountain (Moldavian Carpathians)]. Natura 6:16-20.
Grinţescu G (1952). Asplenium L.. In: Săvulescu T (Ed), Flora Republicii Populare Române, [Flora of the Popular Republic of Romania], vol I, Editura Academiei Republicii Populare Române, Bucureşti pp 125-137.

Guşuleac M (1932). Zur kenntnis der Felsvegetation des Gebirges der Bicaz-Klamm in den Östkarpaten, [Note about the rocks vegetation from Bicaz Gorges in the Eastern Carpathians]. Buletinul Facultății de Ştiințe Cernăuți 6(1-2):307-347.

Hayek A (1916). Die Pflanzendecke Österreich-Ungarns, [The vegetation of Austria-Hungary]. Franz Deuticke, Leipzig und Wien.

Höhn M (1998a). Vascular flora of the Kelemen (Calimani) Mts on the side of the Maros (Mures) river drainage area. Studia Botanica Hungarica 27-28(1996-97):75-108.

Höhn M (1998b). A Kelemen-havasok növényzetéröl, [The vegetation ofCălimani Mountains]. Editura Mentor, Târgu Mureş.

Holderegger R (1994). Zur Farnflora des Pfannenstils, Kt. Zurich, [The ferns from Pfannenstils, Kt. Zurich]. Farnblätter 25:3-21.

Horeanu C (1979). Flora rezervației naturale Munticelu-Cheile Şugăului (județul Neamț), [Flora of Munticelu-Cheile Şugăului natural reserve (Neamţ County)]. Anuarul Muzeului de Ştiinte Naturale Piatra Neamț, Ser Botanică-Zoologie 4:75-86.

Horeanu C, Borcea M (1982). Ceahlăul - viitor parc național, [Ceahlău - future National Park]. Ocrotirea Naturii şi a Mediului Înconjurător 26(1-2):20-33.

Institutul de Cercetări Biologice Iaşi (ICB Iaşi) (1994). Anexa nr 7: Lista speciilor de plante din Călimani, în Parcul Naţional Călimani R. A. Plan de Management 2008, [Annex no 7: The list of plant species in Călimani National Park, Managament Plan-2008]. Retrived 2015 February 04 from http://www.calimani.ro/documente/Plan\%20PNC.zip.

Imbrea I, Nicolin AL, Sorescu C, Corpade C, Buzilă L (2014). Rocks habitats in the Rudăriei Gorges Protected Area. Research Journal of Agricultural Science 46(2):97-105.

IUCN (2012). IUCN Red List Categories and Criteria: Version 3.1. Second edition. Gland, Switzerland and Cambridge, UK: IUCN. iv $+32 \mathrm{p}$.

Klinkerberg B (2008). E-flora BC: Electronic Atlas of the Plants of British Columbia [www.eflora.bc.ca] - Lab for Advanced Spatial Analysis, Department of Geography, University of British Columbia, Vancouver, Retreived 2015 February 02 from http://ibis.geog.ubc.ca/biodiversity/eflora/.

Lovis JD, Reichstein T (1968). Über das spontane Entstehung von Asplenium adulterinum Milde aus einen natürlichen Bastard, [About the spontane origine of Asplenium adulterinum Milde from a natural bastard]. Naturwissenschaften 55(3):117-120.

Manoliu A, Zanoschi V, Coroi A-M, Negrean G, Coroi M, Monah F, Nechita N (2002). Flora Masivului Ceahlău, [Flora of Ceahlău Massif]. Editura Corson, Iaşi.

Mardari C (2008). Aspects of the floristic diversity in Neagra Broştenilor River Basin (Eastern Carpathians) (I). Journal of Plant Development 15:63-68.

Matacă SŞ (2005). Parcul Natural Porțile de Fier. Floră, vegetație si protecția naturii, [Porțile de Fier Nature Park. Flora, vegetation and nature protection]. Editura Universității Craiova. 
306

Milde J (1865). Die Höheren Sporenpflanzen Deutschland's und der Schweiz, [The higher spore plants of Germany and Switzerland]. Leipzig, Verlag von Arthur Felix.

Mititelu D, Viţalariu G, Chifu T, Ştefan N, Dăscălescu D, Horeanu C (1986). Flora Munților Călimani, [Flora of Călimani Mountains]. Analele Ştiințifice ale Universităţii “Al. I. Cuza” Iaşi, Ser II, a. Biologie 32:28-30.

Mititelu D, Chifu T, Pascal P (1989). Flora şi vegetația județului Suceava, [Flora and Vegetation of Suceava County]. Anuarul Muzeului Județului Suceava, Fascicula Ştiințele Naturii 10:93120.

Morariu I (1965). Vegetația şi flora Masivului Rarău, [Vegetation and Flora of Rarău Massif]. In: Cea de-a V-a Consfătuire de Geobotanică pe țară a S. S. N. G. din R. P. R. - Ghid geobotanic pentru Moldova de Nord (23-30 iulie 1965), Bucureşti pp 65-80.

Nagy Ö (1942). Adatok a Székelyföld, különösen a Gyilkostó környékének flórájához [Data about Szeklerland, especially flora of the Lacul Roşu]. Scripta Botanica Musei Transsilvanici 1:9497.

Nechita N (2000). Contribuţii la cunoaşterea vegetaţiei Masivului Hăşmaş (I), [Contributions to knowing of Vegetation of the Hăşmaş Massif (I)]. Studii şi Cercetări, Muzeul de Ştiinţe Naturale Piatra Neamț 9:123-135.

Nechita N (2003). Flora şi vegetaţia cormofitelor din Masivul Hăşmaş, Cheile Bicazului şi Lacul Roşu, [Flora and Vegetation from the Hășmaș Massif, Bicazului Gorges and Lacul Roșu]. Editura Constantin Matasă, Piatra Neamț.

Nechita N, Bliderişanu P (2006). Corologia rarităților floristice din județul Neamț, [The chorology of floristic rarities from Neamț County]. Studii şi Cercetări, Muzeul de Ştiințe Naturale Piatra Neamţ 10:121-129.

Nechita N, Mititelu D (1996). Vegetaţia din Munții Hăşmaş, Cheile Bicazului şi Lacul Roşu, [Vegetation from Hăşmaş Mountains, Bicazului Gorges and Lacul Roșu]. Studii şi Cercetări, Muzeul de Ştiințe Naturale Piatra Neamț 8:213-287.

Nicolin AL, Imbrea IM (2007). Endemic plants in the Miniş Gorges (Almăj Depression). Lucrările Ştiințifice ale Facultății de Agricultură, USAMVB Timişoara 39 (partea a II-a):571-576.

Nicolin AL, Imbrea IM (2009). Aspects of the Flora and Vegetation of the "Izvorul Bigăr" Nature Reserve (South Western Romania). Notulae Botanicae Horti Agrobotanici Cluj-Napoca 37(1):54-58.

Nyárády EI (1924). Contribuțiuni la cunoaşterea vegetaţiei şi florei Muntelui Ceahlău, [Contributions to knowing the Vegetation and Flora in Ceahlău Mountains]. Buletinul de Informații al Grădinii Botanice şi al Muzeului Botanic de la Universitatea din Cluj 4:79-88.

Nyárády EI (1937). A Gyilkostó (Lacul-Roşu) és Békásszoros (Pasul Bicazului) környékének növényzete, [Vegetation around the Lacul Roșu and Bicaz Gorge]. Sibiu.

Oltean M, Negrean G, Popescu A, Roman N, Dihoru G, Sanda V, Mihăilescu S (1994). Lista roşie a plantelor superioare din România, [Red List of superior plants in Romania]. In: Oltean M (Coord), Studii, sinteze, documentații de ecologie. 1. Academia Română, Institutul de Biologie, Bucureşti pp 1-52.
Oprea A (2005). Lista critică a plantelor vasculare din România, [Critical checklist of vascular plants of Romania]. Editura Universităţii „Alexandru Ioan Cuza”, Iaşi pp 18.

Oprea A, Sârbu C (2008). Rare plants in Stânişoara Mountains (Eastern Carpathians). Journal of Plant Development 15:47-61.

Oprea A, Sârbu C (2009). Diversitatea floristică a Munților Stânişoarei (Carpații Orientali), [The floristic diversity in Stânişoarei Mountains (Eastern Carpathians)]. Editura Universităţii „Alexandru Ioan Cuza”, Iaşi pp 36.

Oprea A, Sârbu C (2012). The vascular flora of Rarău massif (Eastern Carpathians, Romania). Note I. Memories of the Scientific Sections of the Roumanian Academy 35:55-84.

Oprea A, Sârbu C (2013). The vascular flora of Rarău massif (Eastern Carpathians, Romania). Note II. Memories of the Scientific Sections of the Roumanian Academy 36:17-52.

Panțu ZC (1911). Contribuțiuni nouă la flora Ceahlăului, [New contributions of the Ceahlău flora]. Analele Academiei Române, Memoriile Secțiunii Ştiințifice, Ser 2, 33(19101911):293-347.

Papp C (1931). O schiță a vegetației masivului Ceahlău, [Vegetation map of Ceahlău Massif]. Revista Ştiințifică „V. Adamachi” 17(2):68-76.

Paucă A (1936). Contribuțiuni la studiul florei munților Codru şi Muma, [Contributions to the flora of the Codru and Muma Mountains]. Analele Academiei Române, Memoriile Secțiunii Ştiințifice, Ser 3 11:1-71.

Paucă A (1941a). A doua contribuțiune la studiul florei munților Codru şi Muma, [A second contributions to the flora of the Codru and Muma Mountains]. Analele Academiei Române, Memoriile Secțiunii Ştiinţifice, Ser 3 15(1939-1940):109-219.

Paucă A (1941b). Studiu fitosociologic în Munții Codru şi Muma, [Phytosociological study in the Codru and Muma Mountains]. $\mathrm{PhD}$ Thesis, Universitatea din Bucureşti.

Peia P (1978). Aspecte de vegetație din Cheile Minişului, [Vegetation aspects from the Minişului Gorges]. Contribuții Botanice:235-250.

Peia P (1982). Rarităţi din Depresiunea Almăjului şi împrejurimi (județul Caraş-Severin), [Rare plants from and the vicinities of Almăjului Depression (Caraș-Severin County)]. Contribuții Botanice:159-160.

Pop I, Hodişan I, Csürös Ş (1969). Aspecte de vegetaţie de pe Valea Eşelnița (M-ții Almăjului, Banat), [Vegetation aspects from the Eșelnița Valley (Almăjului Mountains, Banat)]. Contribuții Botanice:233-243.

Raclaru P (1973). Flora de la Pietrele Doamnei, [Flora of the Lady's Stones]. Studii şi Comunicări de Ocrotirea Naturii Suceava 3:121-133.

Raclaru P (1976). Nouvelles contributions á la flore des Monts Rarău, [New contributions to the flora of the Rarău Mountains]. Acta Horti Botanici Bucurestiensis 19751976:333-336.

Reichstein T (1984). Aspleniaceae. In: Hegi G, Illustrierte Flora von Mittel-Europa, [Illustrated flora of Central Europe]. Band 1, Pteridophyta. Teil 1, Parey, Berlin, Hamburg, Germany pp 211-275. 
Resmeriță I (1970). Taxoni noi şi rari în flora României (Valea Țesna, județul Mehedinți), [New and rare taxons in Romania's flora (Țesna Valley, Mehedinţi County)]. Studii şi Cercetări de Biologie, Ser Botanică 22(3):217-222.

Resmeriță I (1971). Flora Văii Țesna, [Flora of Țesna Valley]. Comunicări de Botanică, Societatea de Ştiinte Biologice 12:133-149.

Resmeriță I (1972). Vegetația lemnoasă din Valea Țesnei, [Woody vegetation from Țesna Valley]. Studii şi Cercetări deBiologie, Ser Botanică 24(4):277-294.

Resmeriţă I, Boşcaiu N, Coldea G, Lupşa V, Schneider E, Stoicovici L (1968). Contribuţii floristice din Defileul Dunării, [Floristic contributions from Danube's Gorges] Comunicări de Botanică, Societatea de Ştiinte Biologice 10:177-180.

Roberts B, Proctor J (1992). The ecology of areas with serpentinized rocks. Geobotany 17:1- 440.

Sârbu I, Ştefan N, Oprea A (2013). Plante vasculare din România: determinator ilustrat de teren, [Vascular Plants from Romania. An illustrated field guide]. Editura Victor B Victor, Bucureşti pp 36-38.

Schneider H, Russell SJ, Cox CJ, Bakker F, Henderson S, Rumsey F, Barrett J, Gibby M, Vogel JC (2004). Chloroplast phylogeny of asplenioid ferns based on rbcL and trnL-F spacer sequences (Polypodiidae, Aspleniaceae) and its implications for biogeography. Systematic Botany 29(2):260-274.

Schrött L (1968). Vegetaţia Rezervației Naturale Cheile Nerei, [Vegetation of the Nerei Gorges Natural Reserve]. Ocrotirea Naturii 12(2):193-201.

Schrött L (1969). Contribuții la cunoaşterea florei Cheilor Nerei, [Contributions to knowing flora of Nerei Gorges]. Comunicări de Botanică, Societatea de Ştiinte Biologice 9:135-140.

Schrött L (1972). Flora şi vegetaţia rezervaţiei naturale BeuşniţaCheile Nerei (Munții Aninei), [Flora and Vegetation of the Beușnița-Nerei Gorges Natural Reserve (Aninei Mountains)]. PhD Thesis Abstract, Universitatea din Bucureşti.

Schrött L (1996). Consideraţii asupra florei şi vegetaţiei din Cheile Nerei (județul Caraş-Severin), [Considerations about the Flora and Vegetations from Nerei Gorges (Caraș-Severin County)]. Annals of West University of Timişoara-Biology 1:13-26.

Seghedin TG (1985). Flora şi vegetaţia vasculară a Munților Bistriței cuprinşi între Văile Bistriței, Neagra Şarului, Neagra şi Negrişoara, [Flora and Vegetation of Bistriţei Mountains between Bistriței Valley, Neagra Șarului, Neagra and Negrişoara]. PhD Thesis, Institutul Agronomic „Ion Ionescu de la Brad" din Iaşi.

Seghedin TG (1987). Studiul florei Munților Bistriței, [The study of the Flora of Bistriței Mountains]. Anuarul Muzeului Județului Suceava, Fascicula Ştiințele Naturii 9:35-46.

Simkovics L (1878). Bánsági s Hunyadmegyei utazásom 1874ben, [Trip in the year 1874 in the Banat and Hunedoara counties]. Mathematikai és Természettudományi Közlemémyek 16:479-624.
Sleep NH, Meibom A, Fridriksson T, Coleman RG, Bird DK (2004). $\mathrm{H}_{2}$-rich fluids from serpentinization: Geochimical and biotic implications. Proceedings of the National Academy of Sciences of the United States of America 101(35):1281812823.

Soó R (1940). A Székelyföld flórájának előmunkálatai. Prodromus Florae Terrae Siculorum (Transsilvaniae orientalis), [Flora of Szeklerland. Prodomus Florae Terrae Siculorum (Eastern Transylvania]. Magyar Flóraművek 3. Instituti Syst.Geobotanici Museique Botanici Universitatis Kolozsvár, ClujNapoca.

Soó R (1943). A Székelyföld flórája, [Flora of Szeklerland]. Magyar Flóraművek 6. Instituti Syst.-Geobotanici Museique Botanici Universitatis Kolozsvár, Cluj-Napoca.

Ştefan N, Mânzu C, Mardari C (2007). Contributions to the study of saxicolous vegetation from Bicaz Gorges (Eastern Carpathians). Romanian Journal of Biology - Plant Biology 51-52(2007):59-76.

Thiers B (2015). Index Herbariorum: A global directory of public herbaria and associated staff. New York Botanical Garden's Virtual Herbarium. Retrieved 2015 February 04 from http://sweetgum.nybg.org/ih/.

Universitatea "Babeş-Bólyai" Cluj-Napoca, Facultatea de Biologie şi Geografie (2006). Cercetări privind flora şi vegetația din parcelele cu pin bănățean din Parcul Naţional DomogledValea Cernei (Proiect LIFE NAT 04/RO/00225 "Pădurile de Pin negru de Banat - parte a rețelei NATURA 2000”), [Research about flora and vegetation of the parcels with Banat black pine from the Domogled-Valea Cernei National Park (Project LIFE NAT 04/RO/00225 - Forests with the Banat black pine - part of the NATURA 2000 network]. Retrieved 2015 February 04 from http://www.domogledcerna.ro/life/Studiu\%20flora.pdf.

Wagner Jr WH, Moran RC, Werth CH (1993). Asplenium adulterinum J. Milde. In: Flora of North America. Retrieved 2015 February 04 from http://www.efloras.org/florataxon.aspx?flora_id=1\&taxon_i $\mathrm{d}=233500190$. 